\title{
Prevalence, Antimicrobial Susceptibility Pattern and Associated Risk Factors for Salmonella Species and Escherichia Coli from Raw Meat at butchery houses in Mekelle, Tigray, Northern Ethiopia
}

HAFTAY Abraha TADESSE ( $\sim$ haftay24@gmail.com )

Mekelle University

Atsebaha Gebrekidan Kahsay

Mekelle University

Dawit Gebreegziabiher Hagos

Mekelle University

\section{Research article}

Keywords: Antimicrobial Susceptibility test, butchery houses, E. coli, raw meat, Salmonella species

Posted Date: June 17th, 2020

DOI: https://doi.org/10.21203/rs.3.rs-35867/v1

License: (c) (i) This work is licensed under a Creative Commons Attribution 4.0 International License. Read Full License 


\section{Abstract}

\section{Background:}

Salmonella species and Escherichia coli (E. coli) are important foodborne pathogens affecting humans and animals. They are among the most important causes of infection that are associated with the consumption of contaminated food. This study was aimed to determine the prevalence, antimicrobial susceptibility patterns and associated risk factors for Salmonella species and E. coli in raw meat from butchery houses of Mekelle, Northern Ethiopia.

\section{Method}

A cross-sectional study was conducted from January to December 2019. Socio-demographic data and risk factors were collected using a predesigned questionnaire. Meat samples were collected aseptically from the butchery houses and transported using icebox to Mekelle University, College of Veterinary Sciences for the isolation and identification of Salmonella species and E. coli. Antimicrobial susceptibility patterns were determined using Kirby disc diffusion method. Data obtained were cleaned and entered into Statistical Package for the Social Sciences version 22 and logistic regression models with odds ratio were calculated. P-value $<0.05$ was considered as statistically significant.

\section{Results}

A total of 153 out of $384(39.8 \%)$ of the meat specimens were found to be contaminated. The contamination of Salmonella species and E. coli were $15.6 \%(n=60)$ and $20.8 \%)(n=80)$, respectively. Mixed contamination (Salmonella species and E. coli) was observed in $13(3.4 \%)$ of the analyzed. Poor washing hands regularly (AOR = 8.37; 95\% Cl: 2.75-25.50) and not using gloves during meat handling (AOR=11. 28; $95 \% \mathrm{Cl}$ :

(4.69-27.10) were associated with an overall bacterial contamination

About $95.5 \%$ of the tested isolates were sensitive to chloramphenicol and norfloxacin while the resistance of amoxyclav_amoxicillin and erythromycin were both isolated bacteria species. The overall multidrug resistance pattern for Salmonella and E. coli were $51.4 \%(n=19)$ and $31.8 \%(14)$, respectively.

\section{Conclusion}

Of the 153 (153/384) contaminated raw meat, 60 (15.6\%) and 80 (20.8\%) were contaminated by Salmonella species and $E$. coli, respectively. Poor handwashing practice and not using glove during meat handling showed significant association with bacterial contamination. Multidrug-resistant showed in Salmonella species and E. coli were $19(51.4 \%)$ and $14(31.8 \%)$, respectively.

\section{Introduction}

Food safety remains a concern of global human health [1]. The difficulties in securing optimal hygienic food handling practices in developing countries are the leads to food contamination [2]. Above two-third, $(70 \%)$ of the diarrheal diseases in developing countries are reported to be the consumption of contaminated food [1]. Food associated with the animal origin is the cause of over $60 \%$ of human pathogens [2]. Meat can be infected or carry a wide range of microorganisms, which are potentially pathogenic for humans [3]. Most of the bacteria that

Loading [MathJax]/jax/output/CommonHTML/jax.js including E. coli and Salmonella species [4, 5].

Page 2/19 
The annual estimated incidence of Salmonella species in the USA is more than 1.2 million illness, 23,000 hospitalizations, and 450 deaths [6] with the highest cost burden [7]. In Europe, infections caused by Salmonella species are the second leading cause of bacterial foodborne illness [8]. The estimated economic burden of human salmonellosis and $E$. coli strain could be high as 3 billion euros per year as reported by the european food safety authority [9].

As indicated in different studies in Ethiopia, the prevalence rate of Salmonella species and E.cooli in raw meat samples were from $2.5-14.7 \%[10-16]$.

Indiscriminate use of antibiotics in livestock production, as well as human diseases in developing countries, lead to increase antimicrobial-resistant (AMR) bacteria [17]. The annual estimated death of individuals due to antimicrobial resistance in the USA and Europe is 23,000 [18] and 25,000[19], respectively. The global death of individuals due to antimicrobial-resistant bacteria estimated to be 700,000 [20].

Meat is highly vulnerable to microbiological hazards and therefore need careful handling, transporting and storing. Un hygienic condition during handling of raw meat during the meat value chain implied a possible risk of infection [21]. Salmonella species and E. coli are among the common bacteria that can contaminate the meat along the meat chain.

Therefore, due to the lack of data in the study area, this study was intended to carry out the prevalence, antimicrobial susceptibility pattern and associated factors for Salmonella species and E. coli from raw meat at butchery houses in Mekelle, Tigray, Ethiopia.

\section{Materials And Methods}

\section{Study area and study design}

The study was conducted in Mekelle, Tigray Regional State, Northern Ethiopia. Mekelle is the capital city of the regional state found located at $390291 \mathrm{E}$ and $130301 \mathrm{~N}$ latitudes and longitude at a distance of $783 \mathrm{Km}$ north of Addis Ababa. The capital city covers an area of 109 square kilometres with an elevation is 2,084 $\mathrm{m} / \mathrm{s}$ above the sea level. The climatic condition of the area is characterized by semi-arid weather with bimodal rainfall patterns, with an average annual rainfall of 479 to $650 \mathrm{~mm}$. The annual average temperature is $20.9^{\circ} \mathrm{C}$ with an annual mean humidity of $75.4 \%$ [22]. A cross-sectional study was conducted from January to September 2019. All the butchery shops in Mekelle City were included in the study.

\section{Sampling technique and size determination}

\section{Sampling technique}

Consecutive sampling technique was employed to recruit the butchery houses. Raw meats from each of the butchery house were collected by using a simple random sampling technique using lottery methods.

\section{Sample size determination}


The sample size was determined using a single proportion. The calculation was based on a prevalence of $50 \%, 5 \%$ desired absolute precision (or error) and $95 \%$ confidence interval using the formula.

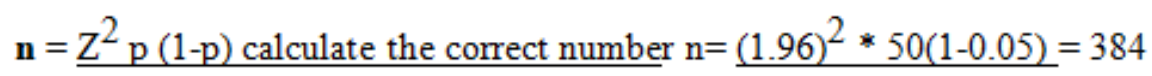
$\mathrm{d}^{2}$
$(0.05)^{2}$

Where $\mathrm{n}$ = required sample size; $\mathrm{p}=$ expected prevalence and a desired absolute precision (d) of 0.05, Z-value = 1.96. Therefore, a total of 384 samples butchery houses used for this study were 384 .

\section{Data Collection and Sample Processing}

Socio-demographic, hygiene and sanitation practice data were collected from the individuals working in the butchery shops. from the study participant in the butchery houses.

\section{Sample collection, handling and transportation}

Raw meat samples were collected in a labelled sterile bottle following aseptic techniques and were transported in a buffer peptone water broth (BPWB) in the icebox to Mekelle University, College of Veterinary Sciences, Microbiology and public health laboratory for microbiological and antimicrobial susceptibility testing.

\section{Bacterial Isolation}

Salmonella species: were isolated and identified according to the technique recommended by the international organization for standardization. Detection of salmonella species was performed using the standard guidelines from ISO 6579: 2002. This isolation and identification procedure involves principal stages including preenrichment, selective enrichment, selective plating and conformation using biochemical test [23].

\section{Preenrichment}

Raw meat specimens were the pre-enriched inappropriate amount of buffered peptone water and lactose broth in (1:9) ratio or twenty-five grams raw meat was placed in $225 \mathrm{ml}$ of peptone water or lactose broth to produce high resuscitation rates for bacteria and promote intense growth. The sample mixture was shaken approximately for 2 minutes and was incubated at $37 \pm 10 \mathrm{C}$ for 24 hours [24].

\section{Selective enrichment}

Selenite $\mathrm{F}$ broth was used for selective enrichment purpose. About $1 \mathrm{ml}$ of the pre-enriched broth was transferred into a tube containing $10 \mathrm{ml}$ of Selenite $\mathrm{F}$ broth and was incubated at $37^{\circ} \mathrm{C}$ for 24 hours [24].

\section{Isolation of Salmonella species}

Xylose lysine deoxycholate (XLD) agar, macConkey ager, salmonella and shigella agar (SSA) and bismuth sulfite (BS) agar plates were used for plating out and identification. A loop full of inoculums from Selenite broth cultures were inoculated into XLD, BS, SSA and MacConkey ager plates and was incubated at $37^{\circ} \mathrm{C}$ for 24 hours. After 
incubation, the plates were examined for the presence of typical and suspect colonies. Typical colonies of Salmonella grown on XLD-agar have a black centre and a light transparent zone of reddish colour due to the colour change of the media while $\mathrm{H} 2 \mathrm{~S}$ negative variants grown on XLD agar are pink with a darker pink centre. On BS agar, Salmonella colonies are brown, grey or black, sometimes with a metallic sheen. Typical colonies of Salmonella on SSA are with a black centre (spot black at centre), $1 \mathrm{~mm}$ to $2 \mathrm{~mm}$ in diameter, and cause the color of medium to change to typical colonies or suspected colonies were selected from the selective plating media, streaked onto the surface of pre-dried nutrient agar plates and incubated at $37^{\circ} \mathrm{C}$ for $24 \mathrm{hrs}$ then indicated to figure $1[24]$.

\section{Isolation of Escherichia coli:}

Isolation of E. coli was conducted following standard procedure. Upon arrival to the laboratory, all pre-enriched buffered peptone water broth raw meat samples were subsequently inoculated to MacConkey agar and were incubated at 37 oc overnight bacterial growth were subjected in to lactose fermenter and non-lactose fermenter and the lactose fermenter colony was sub-cultured to Eosin methylene blue (EMB) agar and were incubated at $37^{\circ} \mathrm{C}$ for 24 hours. Colonies showing typical dark red to purple red with metallic sheen was taken as $E$. coli isolates then indicated to figure 2 [25].

\section{Biochemical Tests}

Identification of Salmonella species and E. coli was done using different biochemical tests including catalase, triple sugar iron (TSI) agar, Methyl red (MR), urease, indole, motility (SIM agar) and citrate tests. Colonies that showed red slant with yellow butt and H2 S production, Indole negative, methyl red positive, citrate positive and urease negative were confirmed as Salmonella species whereas colonies that showed yellow slant and acid butt with no hydrogen sulfide, Indole positive, motile, methyl red positive, citrate negative and urease negative were confirmed as E.coli [25].

\section{Antimicrobial susceptibility testing}

Modified Kirby-Bauer disc diffusion technique was used to perform antimicrobial susceptibility test. The pure colony of E. coli and Salmonella species were tested in separate mueller hinton agar. With a sterile wire loop, five colonies of similar morphological type were transferred to a tube containing $2 \mathrm{ml}$ normal slain solution (NSS). E. coli and Salmonella species separate suspension were prepared and matched with McFarland standard (0.5) and was seeded using applicator cotton swab to the muller-hinton agar and put the paper impregnated antibiotic disks within 15 minutes. Petri-dish was incubated at $370_{C}$ for $16-18$ hrs. After 18 hrs incubation, each plate was examined, and the diameters of the complete inhibition zones noted and measured using callipers and classified as sensitive, intermediate, and resistant by the clinical laboratory standards institute (CLSI) [26]

\section{Data Quality Control}

Data completeness, expired date of media and disks and sterility test of media were performed before data collection and sample inoculation. Quality control strain (E. coli ATCC 35218) was used to check the performance of the media and antibiotic disks.

Loading [MathJax]/jax/output/CommonHTML/jax.js 


\section{Data management and Analysis}

Statistical Package for Social Sciences (SPSS) version 22 software for windows was used. Descriptive analysis was presented using tables. Binomial and multinomial regression was used to determine association contamination rate and bacterial isolates were determined by calculating odds ratio and $95 \%$ confidence interval and P-value $<0.05$ was considered as statistically significant.

\section{Ethical Clearance}

Ethical clearance was obtained from the ethical review board (ERC-1217/2019) of Mekelle University, College of Health Sciences. Study participants and/or their relatives were informed about the procedures and significance of the study. Consent was obtained from participant and owners of the butchery house. Each data results were kept confidentially. All laboratory tests were free of any charge and results were communicated to relevance offices and community for beneficiary measures.

\section{Results}

\section{Socio-demographic characteristics}

Of the total 384 study participants, 344 (89.6\%) were males. The majority 329 (85.7\%) of the study participants were in the age range of 31-40 years. The educational status of $109(28.4 \%)$ and $108(28.1 \%)$ the study participants were college/university and high school, respectively whereas thirty-six of the participants (9.4\%) were illiterates. The work experience of the majority of the participants, 240 (62.5\%) was 2-5 years as indicated in table 1.

\section{Prevalence of Salmonella species and E.coli from raw meat samples}

A total of 384 butchery houses were included in the study. One raw meat sample was from each of the butchery houses. One hundred fifty-three (39.8\%) of meat contaminants (Salmonella and E. coli) were recovered from the collected raw meat specimens. Sixty (15.6\%) Salmonella species, eighty (20.8\%) E. coli and thirteen mixed contamination (3.4\%) (Salmonella and E. coli) were revealed from the raw meat samples.

\section{Associated Risk factors for meat contamination}

Risk factors that showed significant association in multivariate logistic regression analysis of meat contamination were poor regularly washing hands (AOR $=8.37 ; 95 \% \mathrm{Cl}: 2.75-25.50)$ and not using gloves during meat handling and selling (AOR=11. 28; 95\% $\mathrm{Cl}$ : (4.69-27.10) as indicated in table 2.

\section{Associated Risk factors for Salmonella species and Escherichia coli contamination}


Among the associated risk factories of handling money with bare hand during raw meat selling $(A O R=6.98 ; 95 \%$ Cl: 2.46- 19.86), Cutting board can transfer (AOR=10.50; 95\% Cl: 2.49-44.27) and not using gloves during meat handling ( $A O R=4.87 ; 95 \% \mathrm{Cl}: 1.13-21.06)$ were found to be significantly associated with Salmonella species and handling money with bare hand during raw meat selling (AOR=10.89; 95\% Cl: 3.48 - 34.05) and sources of water $(A O R=9.67 ; 95 \% \mathrm{Cl}: 4.22-22.16)$ and poor hand washing regularly (AOR= 56.69; 95\% Cl: $11.95-268.88)$ were found to be significantly associated with $E$. coli as indicated in table 3 .

\section{Antimicrobial Susceptibility Test}

Sixteen antimicrobial discs were used to assess the susceptibility pattern of isolates. All of the tested $(n=44) E$. coli isolates were sensitive to cotrimoxazole, sulfisoxazole/ sulphamethoxazole, trimethoprim, ciprofloxacin, gentamicin and ceftriaxone whereas their sensitivity to nalidixic acid, chloramphenicol, norfloxacin and nitrofurantoin were 93.2\%) (n=41), 95.5\% (n=42), 95.5\% (n=42) and 84.1\%) $(n=37)$, respectively. The sensitivity of $E$. coli to doxycycline hydrochloride, cefotaxime, kanamycin and streptomycin were 27 (61.4\%), 25 (56.8\%), 25 (56.8\%) and 25 (56.8\%), respectively.

Similarly, all of the tested isolates $(n=37)$ of Salmonella species were sensitive to gentamicin, norfloxacin and ciprofloxacin, whereas the sensitivity for nalidixic acid, sulfisoxazole/Sulphametoxazole, trimethoprim, cefotaxime, doxycycline hydrochloride, ceftriaxone, and kanamycin were 35 (94.6\%), 35 (94.6\%), 35 (94.6\%), 31 (83.8\%), 31 (83.8\%), 31 (83.8\%), and 30 (81.8\%), respectively as indicated in table 4.

\section{Multidrug resistance of Salmonella and $E$. coli isolates}

Nineteen (51.4\%) of the isolates of the Salmonella species and fourteen (31.8\%) of the isolates of E. coli were showed multidrug resistance (MDR) in table 5.

\section{Discussion}

Bacterial contaminants of meat were assessed on meat specimen from the butchery houses. Meat contaminants (Salmonella species and E. coli) were detected in 39.8\% (153/384) of the analyzed raw meat samples. Of which, $15.6 \%(n=60)$ and $20.8 \%(n=80)$ of the specimens were contaminated with Salmonella species and E. coli, respectively.

The overall contamination rate of Salmonella species in the butcher shop was $15.6 \%$. This result was in line with prevalence reports from Ethiopia [27-29]. This was higher than the contamination rate reported from retail or butcher shops in Pakistan [30], Burkina Faso [31] and Ethiopia [16, 32-34]. But was lower than other reports from Ethiopia [29, 35-38] and Mexico [39]. The overall contamination rate of E. coli in the butcher shop was 20.8\%. This was consistent with other studies in the United States [40]. But higher than the other reports from Ethiopia [12, 13 and 41]. However, it was lower than reports from Turkey [42], Canada [43], Burkina Faso [31], and Ethiopia [44-47]. The variations in the prevalence of Salmonella species and E. coli might be due to the differences in meat handling for human consumption, personnel hygiene and differences in hygiene measures taking during transportation. Other differences might be differences in sample type, differences in the origin of the samples or by geographical differences, differences in study methods and materials employed by the investigators. 
Antimicrobial-resistant for Salmonella species and E. coli isolates against antibiotics were presented. Salmonella isolates showed resistance to amoxyclav_amoxicillin (86.5\%), erythromycin (56.8\%), nitrofurantoin (43.2\%) and streptomycin $(29.7 \%)$. The resistance rate of nitrofurantoin in this study was in line with another study conducted in Ethiopia [37]. Whereas E. coli isolates showed resistance to amoxyclav_amoxicillin (88.6\%), erythromycin (75\%), cefotaxime (43.2\%), streptomycin 43\%), doxycycline hydrochloride (38.6\%), and kanamycin $43.2 \%)$. The resistance rate of erythromycin [48] and streptomycin [12] conducted in Ethiopia were consistency with the present study. And also streptomycin and cefotaxime which were carried out in Egypt were in line with our present finding [49].

The observed higher level of antimicrobial resistance might be attributed to the widespread and indiscriminate use of antibiotics in animals for medication and other prophylaxis purposes. This difference might be due to small sample sizes for the data, nature of the drug, presence of a different strain of the bacteria, development of resistant gene, their low-frequency usage for prevention and control of disease in food animals in the study area.

Antimicrobial resistance has the potential to adversely affect human health by causing illness that is more difficult to treat because of the resistance profile of the microorganism. This higher resistance profile of both isolates to amoxyclav_amoxicillin (Clavulanic Acid) and erythromycin might be attributed to a high level of utilization of this drug both in veterinary and human medicines due to its relatively cheaper price and ready availability to the local community in the current study area.

The overall multidrug resistance showed in Salmonella species was $51.4 \%$ whereas, for E. coli, the multidrug resistance observed was $31.8 \%$. The multidrug resistance observed in this study showed resistance to three and above different classes of antibiotics [50]. Five (26.3\%), two (10.5\%), one (5.3\%) isolates of Salmonella species showed MDR to three and above, four and five classes of antibiotics respectively. Whereas five (35.7\%), one (7.1\%), one $(7.1 \%)$ isolates of $E$. coli showed MDR to three and above, four and five classes of antibiotics respectively. The MDR finding in the present study was in line with a report from Ethiopia [29]. However, the current finding result was higher than other studies conducted in Ethiopia [28,37]. On the other hand, our finding of multiple drug resistance isolates of E. coli was lower than other reports from Ethiopia, [40, 47 and 48]. This difference in multi-drug resistance development in both Salmonella and E. coli might be due to the widespread and indiscriminate use of the commonly available antimicrobials both in the veterinary and public health practices.

\section{Conclusion}

In the present study, 153 out of $384(39.8 \%)$ of the samples were found to be positive raw meat contamination rate. Poor hand washing regular and not using glove during meat handling showed significant association. Thirty-nine $(88.6 \%)$ and thirty-three (75\%) isolates of $E$. coli showed resistance for amoxiclav-amoxicillin and erythromycin respectively whereas thirty-two (86.5\%) and twenty-one (56.8\%) isolates of Salmonella species revealed resistance for amoxiclav-amoxicillin and erythromycin, respectively. Besides, the prevalence of multiple drug resistance such as $51.4 \%$ of Salmonella species and $31.8 \%$ of E. coli isolates.

There is a need to provide regular training to the butchery houses workers on best practices of food handling in all aspects of food hygiene and safety. Since the current study was conducted in a specific area, it is also recommended that further studies should be made using larger sample size and covering a wider area.

\section{Abbreviations}


MDR= Multidrug-resistant, CLSI = Clinical laboratories Standards institute, SPSS= Statistical Package for Social Sciences

\section{Declarations}

\section{Authors' contributions}

HAT, DG, AGK and MA were participating in designing the proposal, sample collection, experimental work and writing and approving the manuscript. All authors read and approved the final manuscript.

\section{Availability of data and materials}

Not applicable.

\section{Ethics approval and consent to participate}

The study was ethically approved by the ethical review committee of Mekelle University College of Health Sciences.

\section{Consent for publication}

Not applicable.

\section{Competing interests}

The authors declare that they have no competing interests.

\section{References}

1. World Health Origination (WHO). Foodborne Disease. A focus for Health Education, 2000.

2. Jabbar MA, Grace D. Regulations for the safety of animal-source foods in selected Sub-Saharan African countries: Current status and their implications. Prepared for the Safe Food, Fair Food Project. In Livestock Reseach Inst. 2012.

3. Pal M. Raw meat poses public health risks. The Ethiopian Herald 15th May 2012: 2-3.

4. Humphrey T, Jorgensen F. Pathogens on meat and infection in animals: Establishing a relationship using Campylobacter and Salmonella as examples. Meat Sci. 2006;74:89-97.

5. Pal M, Aton J, Paton A. Pathogenesis and diagnosis of Shiga toxin-producing Zoonosis. $2_{\text {nd }}$ Edition. Satyam Publishers, Jaipur, India. 2007: 100-134.

6. CDC. Centres for Disease Control and Prevention. Web site: URL http://www.cdc.gov/media/releases/2014/p0326-salmonella data. 2014.

7. Batz MB, Hoffmann S, Morris JG. Ranking the disease burden of pathogens in food sources in the United States using attribution data from outbreak investigations and expert elicitation. J Food Prot. 2012;75:127891.

8. EFSA-European Food Safety Authority \& ECDC. European Centre for Disease Prevention and Control. The European Union Summary Report on Trends and Sources of Zoonotic Agents and Food-borne Outbreaks in 2012. EFSA J. 2014;12(2):35-47. 
9. EFSA. The European Union summary report on trends and sources zoonosis, zoonotic agents and food-borne outbreaks in 2015. EFSA J. 2016;14:34-46.

10. Tadesse G, Gebremedhin EZ. Prevalence of Salmonella in raw animal products in Ethiopia: a meta-analysis. BMC Research Notes. 2015;8:163.

11. Garedew KL, Wondafrash N, Feleke A. Identification of drug-resistant Salmonella from food handlers at the University of Gondar, Ethiopia. BMC Research Notes. 2014;7:545.

12. Hiko A, Asrat D, Zewde G. Occurrence of Escherichia coli and Salmonella species in retail raw meat products in Ethiopia. J of Infec in Developing Countries. 2008;2(5):389-93.

13. Dulo F, Feleke A, Szonyi B, Fries R, Baumann MPO, Grace D. Isolation of multidrug-resistant Escherichia coli from goats in the Somali region of Ethiopia: a cross-sectional, abattoir based study. PloS one. 2015;10:0142905.

14. Ejeta G, Molla B, Alemayehu D, Muckle A. Salmonella serotypes isolated from minced meat beef, mutton and pork in Addis Ababa, Ethiopia. Revue Méd Vét. 2004;155(11):547-51.

15. Mogessie A. Microbial flora and incidence of some foodborne pathogens on fresh raw beef from butcher $s$ shops in Awassa, Ethiopia. Bull Anim Hlth Prod Afr. 1994;42:273-7.

16. Tassew H, Abdissa A, Beyene G, Gebre-Selassie S. Microbial flora and foodborne pathogens on minced meat and their susceptibility to antimicrobial agents in Jimma Town, southwest Ethiopia. Ethiop J Health Sci. 2010;20(3):137-42.

17. Wendlandt S, Shen J, Kadlec K, Wang Y, Li B, Zhang W, Febler AT, WuC, Schwarz S. Multidrug resistance genes from animals that confer resistance to critically and highly important antimicrobial agents in human medicine. Trends in Microb. 2015;23:44-54.

18. CDC. Summary of Notifiable Infectious Diseases and Conditions - United States. 2015 [Accessed on 16/12/ 2018]; 2017.

19. World Health Organization and European Union. (WHO /EU), [Accessed: 16/12/ 2018]; 2018.

20. Ethiopia Antimicrobial Resistance Surveillance (EARS). Annual Report July 2017 - August 2018 AMR-Report [online] [Accessed: 16/12/ 2018]; 2018.

21. Ministry of Agriculture (MOA). Meat transport and storage guideline, for abattoirs and airport carco terminal workers. Addis Ababa, Ethiopia; 2010.

22. Bryant C. Investment opportunities in Mekelle, Tigray state, Ethiopia, 2016 [online] Available from: Accessed on $21_{\text {th }}$ of May 2017.

23. ISO. Microbiology of Food and Animal Feeding Stuff-Horizontal Method for the detection of Salmonella, International Organization for Standardization (ISO), Geneva, Switzerland, 4th Edit. 2002.

24. El-Shamy HA, Bakr WI, Gomaa NF, Barheem OH. Evaluation of two enrichment broths, three plating media and Elisa technique for the isolation of Salmonella from Dairy Products. J of the Egyptian Public Health Associ. 2008;83:133-7.

25. Quinn P, Carter M, Markey B, Carter G. Clinical Veterinary Microbiology. Enterobacteriaceae. Wolfe Pub. Spain, In, 2002: 209-236.

26. Clinical and Laboratory Standards Institute (CLSI). Performance standards for anti-microbial susceptibility testing; Twenty-Second Informational Supplement. CLSI document. M100-S22. Wayne, PA, 2017. 
27. Ejeta G, Molla B, Alemayehu D, Muckle A. Salmonella serotypes isolated from minced meat beef, mutton and pork in Addis Ababa, Ethiopia. Revue Méd Vét. 2004;155(11):547-51.

28. Mebrat E, Legesse G, Zabishwork A, Walelgn W. Prevalence and Antimicrobial Resistance of Salmonella Isolated from Animal-Origin Food Items in Gondar, Ethiopia Bio-Med Rese Inte. 2016:8.

29. Ashenafi M. Microbial flora and incidence of some foodborne pathogens on fresh beef from butcher's shops in Awasa, Ethiopia. Bull Anim Health Prod Afr. 1994;42:273-7.

30. Ali NH, Farooqui A, Khan A, Khan AY, Kazmi SU. Microbial contamination of raw meat and its environment in retail shops in Karachi. Pakistan J Infect Dev Ctries. 2010;4(6):382-8.

31. AsseTK, Ga KH, Anja S, Alfred ST, Nicolas B. Prevalence of Salmonella enterica and the Hygienic Indicator Escherichia coli in Raw Meat at Markets in Ouagadougou. Burkina Faso Jof Food Protection. 2011;74(9):1547-51.

32. Bayleyegn M, Daniel A, Woubit S. Sources and distribution of Salmonella serotypes isolated from food animals, slaughterhouse personnel and retail meat products in Ethiopia. Eth J Helth Dev. 2003;17:63-70.

33. Mengistu S, Abayneh E, Shiferaw D. E. coli 0157:H7 and Salmonella Species: Public Health Importance and Microbial Safety in Beef at Selected Slaughter Houses and Retail Shops in Eastern Ethiopia. J Vet Sci Technol. 2017;8:468.

34. Zewdu E, Cornelius P. Antimicrobial resistance pattern of Salmonella serotypes isolated from food items and personnel in Addis Ababa, Ethiopia. Trop Anim Health Prod. 2009;41:241-9.

35. Gebeya DN. Prevalence And Antibiotic Resistance of Salmonella Species In Meat Samples taken from a slaughterhouse and selected retail houses in Mekelle, Northern Ethiopia M.Sc. Thesis Haramaya University, 2011.

36. Amenu A Prevalence and Antibiotic Resistance of Salmonella Isolated From Beef in Arbaminch, Southern Ethiopia Haramaya University, MSc. Thesis, 2012.

37. Garedew L, Hagos Z, Addis Z, Tesfaye R, Zegeye B. Prevalence and antimicrobial susceptibility patterns of Salmonella isolates in association with hygienic status from butcher shops in Gondar town, Ethiopia. Antimicrob Res Infec Contr. 2015;4(1):21.

38. Bhandare SG, Sherikarv AT, Paturkar AM, Waskar VS, Zende RJ. A comparison of microbial contamination of sheep/goat carcasses in a modern Indian abattoir and traditional meat shops. Food Contr. 2007;18:854-68.

39. Zaidi MB, McDermott PF, Fedorka-Cray P, Leon V, Canche C, Hubert SK. Non-typhoidal Salmonella from human clinical cases, asymptomatic children, and raw retail meats in Yucatan, Mexico. CID. 2006;42:21-8.

40. Zhao C, Ge JB, Villena RDe, Sudler E, Yeh S, Zhao D, White G, Wagner D, Meng J. Prevalence of Campylobacter spp., Escherichia coli, and Salmonella serovars in retail chicken, turkey, pork, and beef from the Greater Washington, D.C., area. Appl Environ Microbiol. 2001;67:5431-6.

41. Bekele T, Zewde G, Tefera G, Feleke A, Zerom K. Escherichia Coli in raw meat in Addis Ababa, Ethiopia: prevalence at an abattoir and retailers and antimicrobial susceptibility. Inte J Food Contam. 2014;1:4.

42. Siriken B. The microbiological quality of ground beef in Aydin and Afyon Provinces. Turkey Revue Méd Vét. 2004;155(12):632-6.

43. Doyle MP, Schoeni JL. Isolation of Escherichia coli from retail fresh meats and poultry. Appl Environ Microbiolol. 1987;53:2394-6.

44. FAO/WHO (Food and Agriculture Organization and World Health. Organization. FAO/WHO).Guidelines for Loading [MathJax]/jax/output/CommonHTML/jax.js rocessing, 2012. 
45. Haymanot T, Alemseged A, Getenet B, Solomon GS. Microbial flora and foodborne pathogens on minced meat and their susceptibility to antimicrobial agent. Ethiop J Helth Sci. 2010;20:137-43.

46. Girma GM. Antibiogram of Escherichia coli strains disconnected from nourishment of bovine Origin in selected Woredas of Tigray, Ethiopia. Inte J of Bacteriology Rese. 2015;3(4):148-53.

47. Haileselassie M, Taddele H, Adhana K, Kalayou S. Food safety knowledge and practices of abattoir and butchery shops and the microbial profile of meat in Mekelle. Asian Pacific J of Trop Biomedicine. 2013;3:4079.

48. Messele YE, Abdi RD, Shimels TY, Desiye TT, Bezina AE, Gebremeskel MW. Molecular determination of antimicrobial resistance in Escherichia coli isolated from raw meat in Addis Ababa and Bishoftu, Ethiopia. Ann Clin Microbiol Antimicrob. 2017;16:55.

49. Amira AM, Helmut H, Omnia A, Herbert T, Heinrich N, Hafez MH, Hosny ElA. Occurrence of Salmonella enterica and Escherichia coli in raw chicken and beef meat in northern Egypt and dissemination of their antibiotic resistance markers. Gut Pathog. 2017;9:57.

50. Magiorakos AP, Srinivasan A, Carey RB, Carmeli Y, Falagas ME, Giske CG. Multidrug-resistant, extensively drugresistant and pandrug-resistant bacteria: An international expert proposal for interim standard dentitions for acquired resistance. Clin Microbiol Infect. 2012;18:268-81.

\section{Tables}

Table 1: Socio-demographic characteristics of study participates working in the butchery houses in Mekelle, Tigray, Ethiopia, 2019

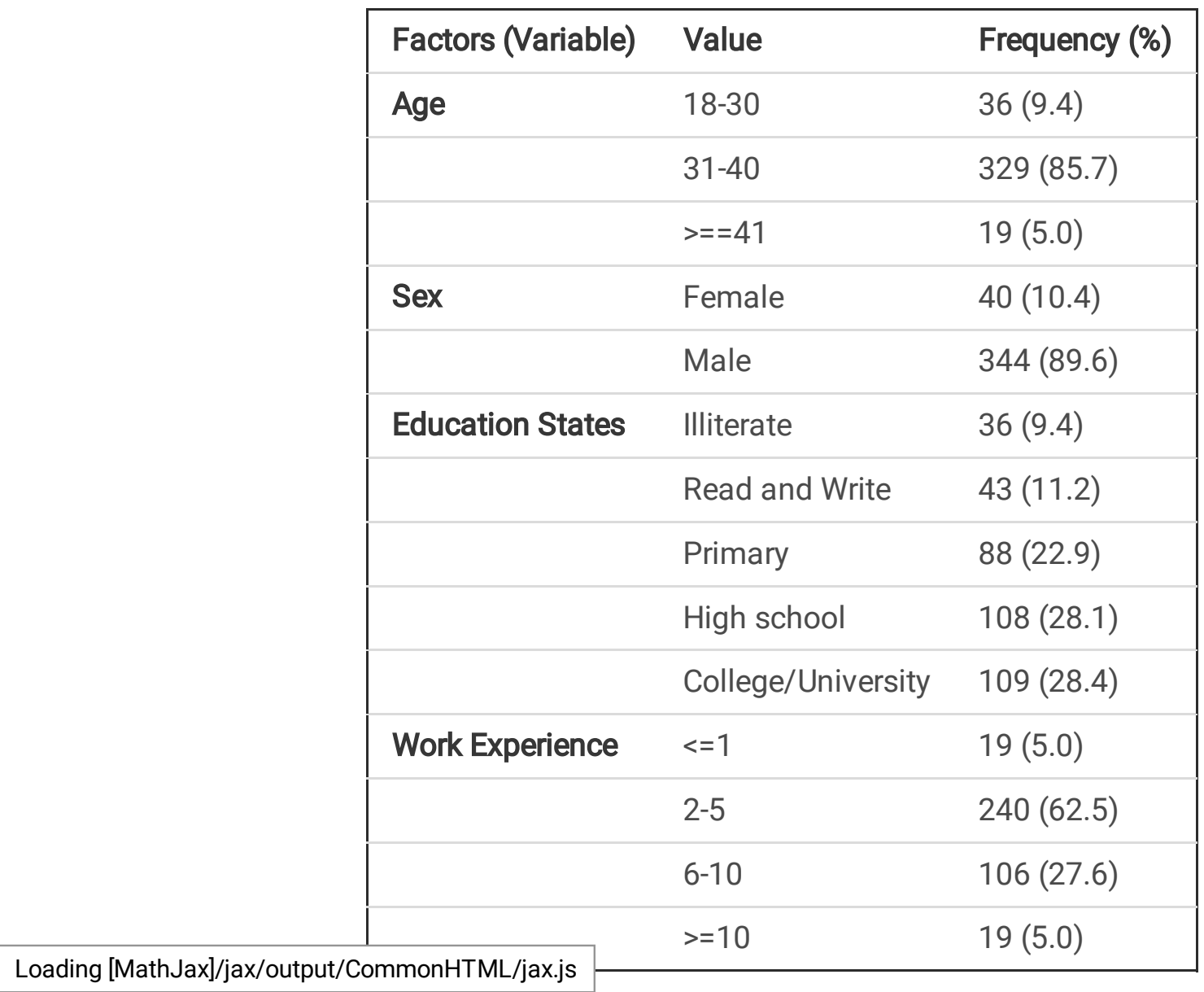

Page 12/19 
Table 2: Risk factors that associated with bacterial isolates from the contaminated meat samples in Mekelle, Tigray, Ethiopia, 2019

\begin{tabular}{|c|c|c|c|c|}
\hline \multirow[t]{2}{*}{ Factors (Variable) } & \multirow{2}{*}{$\begin{array}{l}\text { Frequency } \\
(\%)\end{array}$} & \multicolumn{3}{|c|}{ Bacterial contaminants (Salmonella and E. coli ) } \\
\hline & & COR $(95 \% \mathrm{Cl})$ & AOR $(95 \% \mathrm{Cl})$ & alue \\
\hline \multicolumn{5}{|c|}{ Wash hands regularly } \\
\hline Yes & $185(48.2)$ & Reference & Reference & \\
\hline No & $199(51.8)$ & $\begin{array}{l}84.5(35.3-202.6) \\
0.001\end{array}$ & $\begin{array}{l}8.37(2.75-25.50) \\
0.001\end{array}$ & \\
\hline \multicolumn{5}{|l|}{ Using gloves } \\
\hline Yes & $181(47.1)$ & Reference & Reference & \\
\hline No & $203(52.9)$ & $\begin{array}{l}43.3(21.8-86.1) \\
0.001\end{array}$ & $\begin{array}{l}11.28(4.69-27.10) \\
0.001\end{array}$ & \\
\hline \multicolumn{5}{|c|}{$\begin{array}{l}\text { Strict Separation b/n clean \& } \\
\text { dirty }\end{array}$} \\
\hline Yes & $189(49.2)$ & Reference & Reference & \\
\hline No & $195(50.8)$ & $\begin{array}{l}0.53(0.35-0.81) \\
0.003\end{array}$ & $\begin{array}{l}0.38(0.17-0.85) \\
0.019\end{array}$ & \\
\hline \multicolumn{5}{|c|}{ Knife can be transfer disease } \\
\hline Yes & $185(48.2)$ & Reference & Reference & \\
\hline No & $199(51.8)$ & $\begin{array}{l}44.7(21.97-90.85) \\
0.001\end{array}$ & $3.33(1.16-9.56)$ & 0.025 \\
\hline \multicolumn{5}{|c|}{ Cleaning equipment's After work } \\
\hline Yes & $184(47.9)$ & Reference & Reference & \\
\hline No & $200(52.1)$ & $\begin{array}{l}60.9(28.02-132.5) \\
0.001\end{array}$ & $6.08(2.08-17.82)$ & 0.001 \\
\hline
\end{tabular}

Cl-Statistically significant at 95\% confidence interval, p-value $=0.05 \%$, COR-Crude Odds Ratio, AOR-Adjusted Odds Ratio

Table 3: Risk factors associated with Salmonella species and E. coli isolates from contaminated raw meat in Butchery houses of Mekelle, Tigray, Ethiopia, 2019 


\section{Factors (Variable)}

Freq
$(\%)$

Salmonella species

COR $(95 \% \mathrm{Cl})$

AOR

$(95 \% \mathrm{Cl})$
Escherichia coli

$\operatorname{COR}(95 \% \mathrm{Cl}) \quad$ AOR $(95 \% \mathrm{Cl})$

Wash hands regularly

\begin{tabular}{llllll} 
Yes & 185 & Reference & \multicolumn{3}{c}{ Reference } \\
& $(48.2)$ & & & \\
& & & & & \\
No & 199 & $24.57(8.720-$ & $1.49(0.23-$ & $83.73(20.19-$ & $56.69(11.95-$ \\
& $(51.8)$ & $69.244)^{\star}$ & $9.59)$ & $347.29)^{\star}$ & $264.88)^{\star}$
\end{tabular}

Washing hand properly

Yes

No

Using gloves

Yes

No

181

(47.1)

203

(52.9)
184

(47.9)

(52.1)
Reference

$13.01(5.76-$

$29.41)^{\star}$
$0.61(0.12$

$-3.04)$

Reference

$21.21(9.45-$

$47.60)^{*}$

1.19 (0.17-

8.32)

$56.69(11.95$

64.88) 


\begin{tabular}{|c|c|c|c|c|c|}
\hline Yes & $\begin{array}{l}174 \\
(45.31)\end{array}$ & Reference & & Reference & Reference \\
\hline No & $210(54.7)$ & $\begin{array}{l}3.09(1.69- \\
5.65)^{\star}\end{array}$ & $\begin{array}{l}1.04(0.41- \\
2.59)\end{array}$ & $\begin{array}{l}10.83(5.24- \\
22.41)^{\star}\end{array}$ & $\begin{array}{l}4.68(1.69- \\
12.93)^{\star}\end{array}$ \\
\hline \multicolumn{6}{|l|}{ Handling money } \\
\hline Cashier & $\begin{array}{l}188 \\
(48.96)\end{array}$ & Reference & Reference & Reference & Reference \\
\hline Butcher with Bare hands & $\begin{array}{l}196 \\
(51.04)\end{array}$ & $\begin{array}{l}14.01(5.49- \\
35.80)^{\star}\end{array}$ & $\begin{array}{l}6.98(2.46- \\
19.86)^{*}\end{array}$ & $\begin{array}{l}17.82(7.54- \\
42.14)^{*}\end{array}$ & $\begin{array}{l}10.89(3.48- \\
34.05)^{\star}\end{array}$ \\
\hline \multicolumn{6}{|l|}{ Cutting table } \\
\hline Separate for difference & $188(49)$ & Reference & Reference & Reference & Reference \\
\hline Single & $209(54.4)$ & $\begin{array}{l}0.20(0.11- \\
0.38)^{\star}\end{array}$ & $\begin{array}{l}0.16(0.07- \\
0.33)^{\star}\end{array}$ & $\begin{array}{l}1.66(1.02- \\
2.68)^{\star}\end{array}$ & $\begin{array}{l}5.15(2.11- \\
12.57)^{\star}\end{array}$ \\
\hline
\end{tabular}

*-Statistically significant at 95\% confidence interval, COR-Crude Odds Ratio, AOR-Adjusted Odds Ratio

Table 4: Antimicrobial susceptibility patterns of E. coli and Salmonella species isolates from contaminated raw meat in Butchery houses of Mekelle, Tigray, Ethiopia, 2019 


\begin{tabular}{|lllllll|}
\hline Antibiotic type & \multicolumn{5}{l}{ Status of an antimicrobial agent against the isolates } \\
\cline { 2 - 7 } & \multicolumn{2}{c}{ E. coli (n=44) } & \multicolumn{5}{c|}{ Salmonella species (n=37) } \\
\hline Nalidixic Acid & - & $3(6.8)$ & $41(93.2)$ & $2(5.4)$ & - & $35(94.6)$ \\
\hline Norfloxacine & $2(4.5)$ & - & $42(95.5)$ & - & - & $37(100)$ \\
\hline Chloramphenicol & $2(4.5)$ & - & $42(95.5)$ & $3(8.1)$ & $11(29.7)$ & $23(62.2)$ \\
\hline Trimethoprim & - & - & $44(100)$ & $2(5.4)$ & - & $35(94.6)$ \\
\hline Ciprofloxacin & - & - & $44(100)$ & - & - & $37(100)$ \\
\hline Erythromycin & $33(75)$ & $5(11.4)$ & $6(13.6)$ & $21(56.8)$ & $2(5.4)$ & $14(37.8)$ \\
\hline Gentamicin & - & - & $44(100)$ & - & - & $37(100)$ \\
\hline Kanamycin & $19(43.2)$ & - & $25(56.8)$ & - & $7(18.2)$ & $30(81.8)$ \\
\hline Streptomycin & $19(43.2)$ & - & $25(56.8)$ & $11(29.7)$ & - & $26(70.3)$ \\
\hline Sulphamethoxazole & - & - & $44(100)$ & - & $2(5.4)$ & $35(94.6)$ \\
\hline Ceftriaxone & - & - & $44(100)$ & $4(10.8)$ & $2(5.4)$ & $31(83.8)$ \\
\hline Co-trimoxazole & - & - & $44(100)$ & $2(5.4)$ & - & $35(94.6)$ \\
\hline Nitrofurantoin & $1(2.3)$ & $6(13.6)$ & $37(84.1)$ & $16(43.2)$ & $5(13.5)$ & $16(43.3)$ \\
\hline Cefotaxime & $19(43.2)$ & - & $25(56.8)$ & $5(13.5)$ & $1(2.7)$ & $31(83.8)$ \\
\hline Doxycycline & $17(38.6)$ & - & $27(61.4)$ & $6(16.2)$ & - & $31(83.8)$ \\
\hline Amoxyclav_Amoxicillin & $39(88.6)$ & $3(6.8)$ & $2(4.6)$ & $32(86.5)$ & $3(8.1)$ & $2(5.4)$ \\
\hline
\end{tabular}

I= Intermediate, $\mathrm{R}=$ Resistance $\mathrm{S}=$ Sensitive

Table 5: Multiple drug resistance of Salmonella and $E$. coli isolates from contaminated raw meat in Butchery houses of Mekelle, Tigray, Ethiopia, 2019 


\begin{tabular}{|c|c|c|c|c|c|c|c|c|c|c|c|c|}
\hline \multirow{2}{*}{$\begin{array}{l}\text { Anti- } \\
\text { microbial }\end{array}$} & \multicolumn{6}{|c|}{ Salmonella species $(\mathrm{N}=37)$} & \multicolumn{6}{|c|}{ E. coli $(\mathrm{N}=44)$} \\
\hline & \multicolumn{5}{|c|}{ Resistance pattern } & $\begin{array}{l}\text { Isolates } \\
\mathrm{N} \text { (\%) }\end{array}$ & \multicolumn{5}{|c|}{ Resistance pattern } & $\begin{array}{l}\text { Isolates } \\
\mathrm{N}(\%)\end{array}$ \\
\hline \multirow[t]{6}{*}{ Three } & E & NIT & DO & & & $1(5.3)$ & NX & DO & AMC & & & $2(14.3)$ \\
\hline & E & NIT & AMC & & & $5(26.3)$ & NX & E & AMC & & & $1(7.1)$ \\
\hline & C & E & AMC & & & $1(5.3)$ & CTX & E & AMC & & & $1(7.1)$ \\
\hline & S & DO & AMC & & & $1(5.3)$ & E & DO & AMC & & & $5(35.7)$ \\
\hline & TR & E & AMC & & & $1(5.3)$ & E & S & AMC & & & $1(7.1)$ \\
\hline & & & & & & & E & CTX & AMC & & & $1(7.1)$ \\
\hline \multirow[t]{7}{*}{ Four } & C & E & NIT & AMC & & $1(5.3)$ & C & E & DO & AMC & & $1(7.1)$ \\
\hline & E & S & DO & AMC & & $2(10.5)$ & E & NIT & DO & AMC & & $1(7.1)$ \\
\hline & C & E & NIT & AMC & & $1(5.3)$ & & & & & & \\
\hline & E & S & DO & AMC & & $1(5.3)$ & & & & & & \\
\hline & NA & CTR & CTX & AMC & & $1(5.3)$ & & & & & & \\
\hline & TR & E & NIT & AMC & & $1(5.3)$ & & & & & & \\
\hline & E & NIT & DO & AMC & & $1(5.3)$ & & & & & & \\
\hline Five & E & CTR & СOT & CTX & AMC & $1(5.3)$ & E & K & $S$ & CTX & AMC & $1(7.1)$ \\
\hline \multicolumn{6}{|c|}{ Total MDR isolates } & 19(51.4) & & & & & & $\begin{array}{l}14 \\
(31.8)\end{array}$ \\
\hline
\end{tabular}

NB: AMC: Amoxyclav_Amoxicillin (Clavulanic Acid), CIP: Ciprofloxacin, C: Chloramphenicol, COT: Cotrimoxazole (Trimethoprim/Sulphamethoxazole), CTR: Ceftriaxone, CTX: Cefotaxime (Cephotaxime), DO: Doxycycline Hydrochloride, E: Erythromycin, GEN: Gentamicin, K: Kanamycin, NA: Nalidixic Acid, NIT: Nitrofurantoin, NX: Norfloxacin, S: Streptomycin, SF: Sulfisoxazole/Sulphamethoxazole and TR: Trimethoprim

\section{Figures}




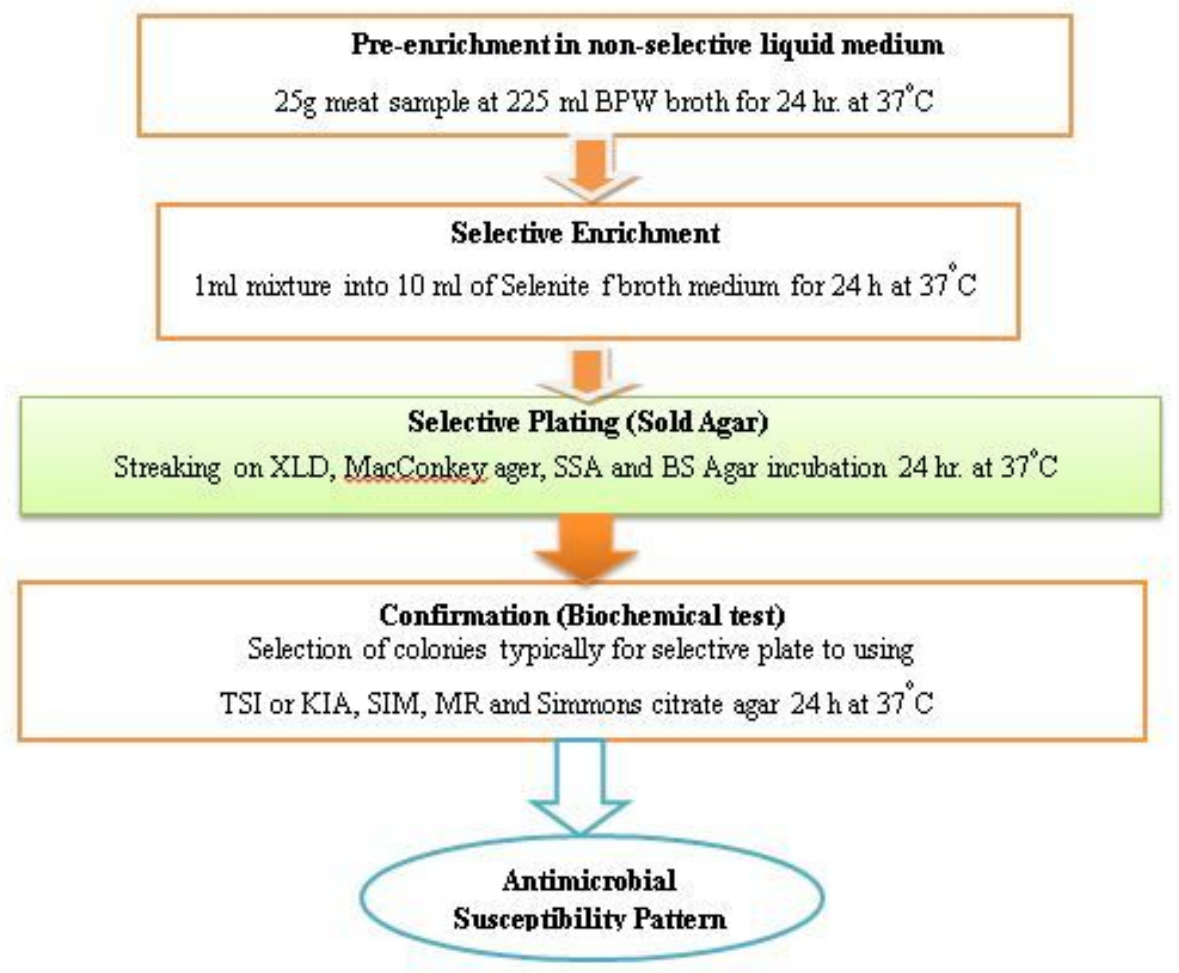

Figure 1

Schematic procedure for Salmonella species isolation 
Pre enrichment

$25 \mathrm{~g}$ meat sample at $225 \mathrm{ml}$ BPW broth for $24 \mathrm{hr}$ at $37^{\circ} \mathrm{C}$

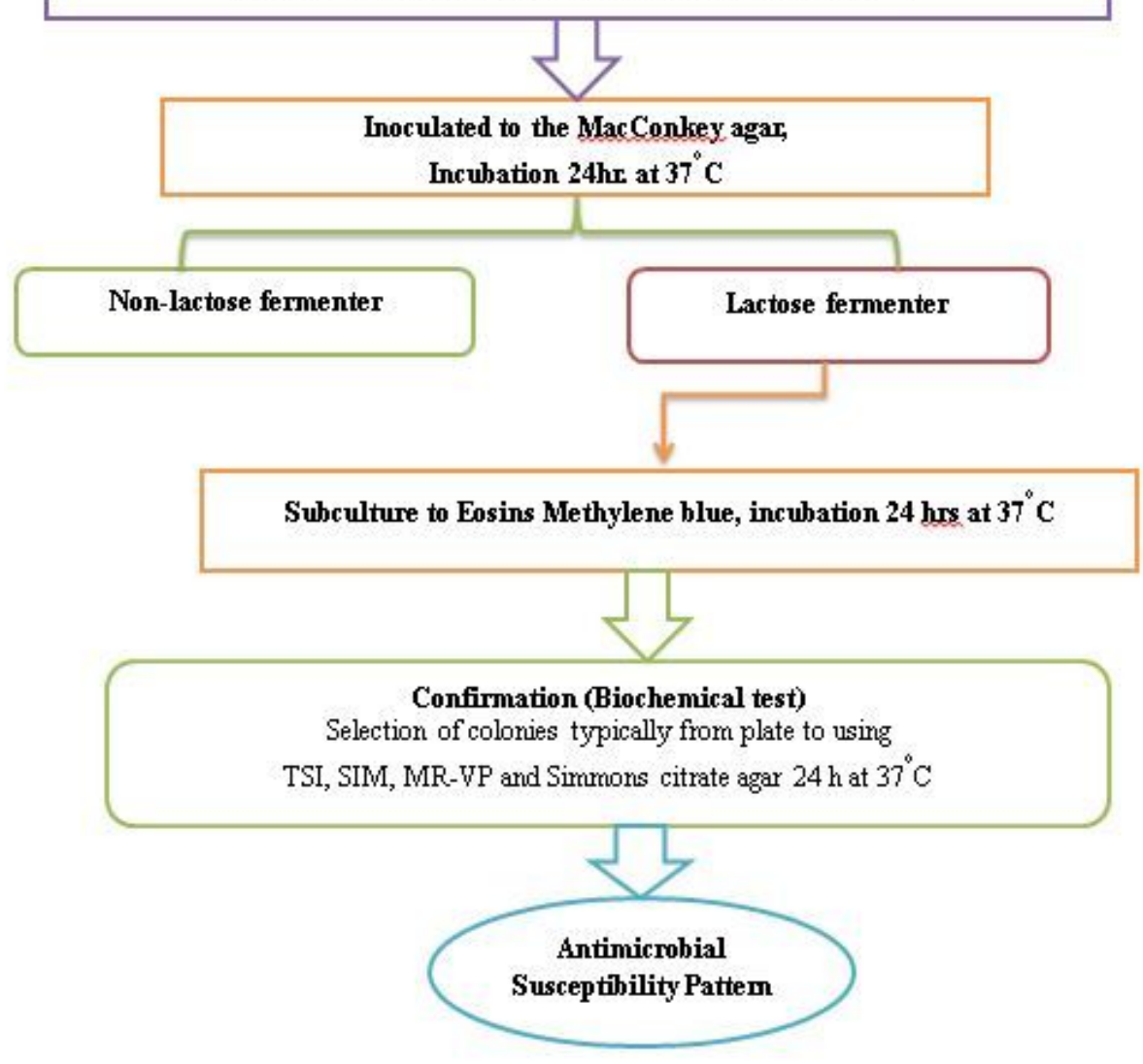

Figure 2

Schematic procedure for Escherichia coli isolation 